\title{
O interesse e a regra: ensaios sobre o multilateralismo*
}

\author{
LEANDRO FREITAS COUTO**
}

O conjunto de ensaios sobre o multilateralismo reunido pelo embaixador Gelson Fonseca Jr em "O interesse e a regra" revelam as preocupaçōes do autor sobre o papel a ser cumprido pela Organização das Naçôes Unidas na ordem internacional do século XXI. O livro é dividido em um artigo central, inédito, escrito depois de o autor ter deixado suas funçôes na ONU, e outro cinco artigos escritos há mais tempo, já publicados, que dialogam com o texto principal na medida em que tratam de temas que muitas vezes se cruzam e se complementam.

$\mathrm{O}$ artigo central discute a importância da referência de legitimidade emanada das Nações Unidas na dinâmica de contraposição constante que existe entre os interesses particulares dos Estados nacionais e o conjunto de regras e normas construído na arena multilateral. A busca pela legitimidade das ações internacionais dos estados nacionais no palco global é que faria a mediação entre o particular e o universal, entre a vontade individual e a norma multilateral. No texto, rico em exemplos históricos, fruto da vasta experiência do autor enquanto diplomata e estudioso das relações internacionais, o autor esquiva-se de se referenciar exclusivamente a uma linha teórica para entender o fenômeno do multilateralismo onusiano. Embora parte do artigo seja dedicada a desenvolver as idéias de John Ruggie, perspectivas funcionalistas, construtivistas e realistas alternam-se ao longo do texto. Frente à complexidade e à diversidade dos temas analisados, essa escolha se converte em um trunfo do artigo.

$\mathrm{O}$ autor reconhece que a $\mathrm{ONU}$ forja seu lugar em meio às influências políticas e econômicas dos Estados, que condicionam a oferta dos serviços prestados pela instituição. $\mathrm{O}$ fórum multilateral, mais do que resolver, expressa as desigualdades intrínsecas ao sistema internacional contemporâneo, revelando-as. A capacidade multilateral dos países é distinta, sendo que o recurso ao soft power é importante para prevalecer na ONU, principalmente na articulação da identificação do argumento individual com o interesse da comunidade internacional. Assim, mesmo quando se está de acordo quanto aos fins, a ONU enfrente problemas

\footnotetext{
* Resenha de FONSECA JUNIOR, Gelson. O interesse e a regra: ensaios sobre o multilateralismo. São Paulo: Paz e Terra, 2008. 362 p. ISBN 978-85-7753-072-4.

** Analista de Planejamento e Orçamento do Ministério do Planejamento, Orçamento e Gestão, Mestre e Doutorando em Relações Internacionais pela Universidade de Brasília - UnB (leandro.couto@gmail.com).
} 
para articular os meios necessários à sua implementação. E a irregularidade passa a ser uma marca constante da sua oferta multilateral.

A ONU, contudo, conforme assinala o autor, dispóe de uma oferta ampla e consolidada de serviços que, embora seja de prestação irregular e não exclusivo da instituição, continuam sendo a referência de legitimidade para a comunidade internacional. Os estados a usariam tanto na construção dos argumentos no fórum multilateral, na intenção de transmutar o interesse particular em vontade multilateral, como considerariam os constrangimentos que surgiriam a partir de uma atuação que contrariasse suas orientações, resoluções ou normas.

Nisso, há outro importante ponto do argumento do autor, de que há graus diferentes de legitimidade que podem ser emprestadas pela ONU. Desde uma resolução sem voto da Assembléia Geral, de consenso fluido até normas mais firmes e precisas de tradução imediata ao comportamento dos Estados. Analisando as transformações da legitimidade, o autor investiga três temas: a atuação do Conselho de Segurança, a importância da ONU para o processo de descolonização africana e a atuação da instituição em temas relacionados ao desenvolvimento.

Completam a obra um artigo sobre a governabilidade democrática na ordem internacional e os seus reflexos sobre os graus de legitimidade das Naçóes Unidas, dois artigos com foco regional, um a respeito das articulaçōes de posiçōes da América Latina e Europa na ONU e outro sobre as possibilidades da CPLP no multilateralismo contemporâneo, além de um artigo que discute como uma ordem multipolar afetaria o funcionamento do multilateralismo. Fecha o livro o texto de introdução à obra Rousseau e as Relações Internacionais (2005).

Nada pode indicar que a ONU deixará de ser um ator importante na ordem internacional que atualmente se engendra. $\mathrm{O}$ maior risco à $\mathrm{ONU}$, apontado por Gelson Fonseca, é justamente de perder a referência de legitimidade, principalmente no "quase" monopólio que detém para promover a paz. As utopias políticas regem os atores. $\mathrm{Na}$ falta delas, o interesse particular é o norte. Uma ONU forte, ainda que imperfeita, mas referência de legitimidade na cena internacional, é uma utopia válida aos dias atuais de renovação do espírito multilateral, o que confere a pertinência e a relevância ao livro de Gelson Fonseca Jr.

Recebido em 6 de junho de 2009 Aprovado em 10 de setembro de 2009 